\title{
Digital Leisure: An Opportunity for Intergenerational Well-Being in Times of Pandemic?
}

\author{
Rosa Ana Alonso Ruiz (D), Magdalena Sáenz de Jubera Ocón (1), María Ángeles Valdemoros San \\ Emeterio ${ }^{\circ}$ and Ana Ponce de León Elizondo (1)
}

Department of Educational Sciences, University of La Rioja, Spain

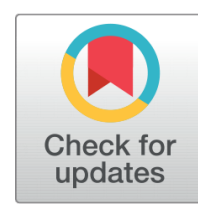

Received 2021-06-22
Revised 2021-06-29
Accepted 2021-09-10
Published 2022-01-15

Corresponding Author

Rosa Ana Alonso Ruiz,

rosa-ana.alonso@unirioja.es

C/ Luis de Ulloa, 2. 26004

Logroño, La Rioja, Spain.

DOI https://doi.org/10.7821/ naer.2022.1.806

Pages: 31-48

Funding: Ministry of Science and Innovation, Spain

(Award:EDU2017-85642-R,

PID2020-119438RB-I00)

Distributed under

CC BY-NC 4.0

Copyright: ( ) The Author(s)

\section{ABSTRACT}

Leisure activities shared by grandparents and grandchildren provide important benefits. The health and humanitarian crisis caused by the coronavirus (COVID-19) pandemic has made it necessary to use digital tools to alleviate the lack of contact between adults and children. This paper had as its aim to identify the digital leisure shared by grandparents and their pre-adolescent grandchildren (10-12 years old) before and during the pandemic, as well as its contribution to intergenerational well-being from a holistic paradigm, ultimately aiming to determine whether that digital leisure constitutes an experience of human development for young and old people alike. The sample was made up of 153 grandparents of 10-to-12-year-old children living in the north of Spain. Alongside the use of an ad hoc questionnaire, descriptive and inferential analyses were carried out. Most intergenerational leisure activities ceased to be performed during the lockdown, except for those that could be carried out remotely, thanks to information and communication technologies, which ensured the continuity of social and family interactions. Technological connectivity between generations provided greater support to communication and meaningful relationships, additionally facilitating active aging processes.

\section{Keywords LEISURE, DIGITAL, GRANDPARENTS, GRANDCHILDREN,} WELL-BEING

\section{INTRODUCTION}

In recent decades, the scientific literature has paid special attention to research focused on intergenerational relationships between grandparents and grandchildren. Demographic, sociocultural, and family changes have increased life expectancy, and the greater extent to which both generations are interacting has helped raise growing interest in this topic (Ramos, 2019). Previous studies emphasized that the relationships between grandparents and grandchildren are characterized by closeness, as well as by being very meaningful for the two groups involved. Grandchildren acknowledge their grandparents as relevant agents in their care, protection, and attention (Attar-Schwartz, Tan, \& Buchanan, 2009), the latter in turn feeling strongly attached to the former (Triadó, 2000; Triadó,

\section{OPEN ACCESS}


Martínez, \& Villar, 2000). However, authors such as Luna, Ramos, and Rivera (2016) observed stress reactions in grandparents when they are faced with intensive or assiduous obligations and the care of their grandchildren, engaging in these tasks either on a full-time or a part-time basis (Buchanan, 2008). Other studies showed that intergenerational exchanges taking place in moments of family leisure and activities -such as sharing meals, talking, listening to music, speaking on the phone, telling stories, playing, or going for walks- privileged interactions and notable benefits for both generations (Coall \& Hertwig, 2010; González-Bernal \& Fuente, 2007; Kim, Kang, \& Johnson-Motoyama, 2017; Pinazo \& Montoro, 2004).

Numerous studies (Álvarez, Cala, \& Riaño, 2019; Aranda, 2013; Lloyd, 2008; MacCallum et al., 2006; Martínez, 2017; Miguel, Escarbajal, \& Moreno, 2012) have identified social, emotional, and even instrumental or financial benefits derived from grandparentsgrandchildren intergenerational relationships. These materialize in benefits involving the transmission of life skills, abilities, or knowledge, emotional and social values (self-esteem, self-confidence, and tolerance in the face of adversity), together with the transmission and reproduction of culture and history, as well as identity. Likewise, such relationships help not only prevent and reduce prejudices, harmful habits, and ageism but also bring advantages concerning the experiential meaning of intergenerational exchanges, providing vitality, optimism, motivation, and personal esteem. In this sense, both the contributions and the time shared by grandparents and grandchildren enhance the quality of these relationships and the maintenance of intergenerational solidarity, which, in turn, generates wellbeing and promotes an active, satisfactory, and successful aging process (Badenes \& López, 2011; Martínez, 2017).

The current health and humanitarian crisis caused by the coronavirus (COVID-19) pandemic has transformed family interactions and, more specifically, intergenerational relationships between grandparents and grandchildren. The periods of confinement at home, together with the mobility restrictions implemented to reduce the level of transmission of the virus, have limited the contact between these two groups, especially due to elderly people's vulnerability. These restrictions combined with the lack of family and social interactions frequently cause restlessness and discomfort among minors and their grandparents and can even lead to emotional and psychological consequences for the children and particularly for the old ones, who yearn for shared moments (Alonso, Jubera, \& Sanz, 2020; Brooks et al., 2020; Dalton, Rapa, \& Stein, 2020). The exceptionality of the global pandemic situation experienced during 2020 posed a huge challenge. We were accustomed to living in a culture characterized by a high level of sociability, based on affection and physical accompaniment, which encouraged the use of technologies to ensure the continuity of social and family interactions (Ayuso, Requena, Jiménez, \& Khamis, 2020). However, the Digital Economy and Society Index (DESI) 2020 stated that 43\% of individuals between 16 and 74 years of age lack basic digital skills. The pandemic has triggered a high demand for digital infrastructure and services, though.

The importance attributed to technology becomes evident in the scientific literature highlighting the access, social impact, and benefits of using the Internet (Cloquell, 2015; 
Ochaita, Espinosa, \& Gutiérrez, 2011). An urgent need exists to encourage education and digital inclusion among older people segments, since evidence has been provided of the key role played by technology for communication with both the family and the social environment in times of confinement (Jones, 2020; Osorio, Jorquera, \& Araya, 2021). Technology also acquires relevance when it comes to coping with loneliness and preventing medical syndromes derived from the decreased physical and social stimuli older people (Armitage \& Nellums, 2020). It has been shown that the roles of main creative agents and editors of their virtual spaces as well as that of real consumers of digital communication and managers of virtual social networks corresponds to young people (Colás, González, \& Pablos, 2013; Espinar \& González, 2009; Llamas \& Pagador, 2014; Subrahmanyam, Greenfield, \& Michikyan, 2015; Valdemoros, Alonso, \& Codina, 2018; Valdemoros, Sanz, \& Ponce, 2017). The study authored by Freeman et al. (2020) reported that older people are not opposed to technology and actually take advantage of intergenerational relationships to more easily adapt to the use of digital devices, computers, and social networking sites, so that they can remain connected to their relatives, especially when a geographical separation exists between them.

The changing, communicative, and heterogeneous technological vision that is integrated into our society's daily life has caused recent research to focus not only on technology aimed at intergenerational connectivity as an emerging field but also on the design of technology intergenerational digital games (Ayuso et al., 2020; Canedo, Pachero, García, \& Gonçalves, 2018; Drury \& Bobrowicz, 2017; Hera, Loos, Simons, \& Blom, 2017; Reis, Mercer, \& Boger, 2021). Other studies which have analyzed how which perceptions about technology and its use relate to intergenerational relationships (Freeman et al., 2020) treated digital inclusion as a relevant alternative in the active aging process that should ultimately seek the incorporation of older people into the information and knowledge society (Arroyave, Ocampo, Sánchez, \& Vega, 2020).

Within this trend of increasing, massive, and rapid integration of information and communication technologies (ICTs) into the domestic sphere, intergenerational support becomes crucial to help older people remain independent and age at home, both in cities and in rural areas (Freeman et al., 2020). Conversely, a limited access to technology or a limited ability to use it, referred to as the "generational digital gap," can become a distinct risk factor for depression and loneliness in this world mediated by digital technologies (Ayalon et al., 2021; J. Jimena, 2020; Martín-Romero, 2020). Research has increasingly reached a consensus on the fact that technology plays a potentially key role in boosting intergenerational connectivity and activating solidary networks (Ayuso et al., 2020; Reis et al., 2021).

Intergenerational technological connectivity between grandparents and grandchildren is largely reinforcing communication and meaningful interactions, a positive influence on the improvement of older people's quality of life, as well as a boost to facilitate active aging processes (Arroyave et al., 2020; Ayuso et al., 2020; Casamayou \& Morales, 2017; Rivoir, Morales, \& Casamayou, 2019). Grandparents have had to become digitally literate in a very short period of time, so that they could maintain daily online contact with their relatives. Clearly, reciprocal feelings between the two generations under examination were hardly 
affected thanks to the use of ICTs (Cambero, 2020). Within the context of intergenerational relationships, it is interesting to consider the results obtained in the research work undertaken by Barrio and Gutiérrez (2015), who suggest a more widespread use of technologies among adolescents who live with their grandparents. Likewise, the age of those involved leads to adapt functions and preferences in their relationships, generating different needs based on development and maturity aspects (González-Bernal \& Fuente, 2006; R. Jimena, 2017).

Summing up, in addition to supporting the maintenance of intergenerational communicative relationships, digital inclusion arises as a relevant strategy to share learning, to enhance cognitive capacity, and to promote autonomy as well as solidarity between generations (Ayuso et al., 2020; Carcavilla, 2014; Rivoir et al., 2019).

This study aimed to examine the digital leisure shared by grandparents and their preadolescent grandchildren (10-12 years) before and during the pandemic, as well as the contribution made by that digital leisure to intergenerational well-being from a holistic paradigm (physical, emotional, and social), for the purpose of determining whether it constitutes a true experience of human development for the young and the old alike.

\section{MATERIAL AND METHODS}

\subsection{Participants}

The study was conducted with 153 grandparents of 10-to-12-year-old children who lived in the northern part of Spain (including 8 provinces distributed across 5 Autonomous Regions: Cantabria, Castile and León, Navarre, the Basque Country and La Rioja).

Before the outbreak of the pandemic, 357 grandparents with grandchildren enrolled in Primary Education (6-12 years of age) had already been interviewed. Then, in an attempt to curb the transmission of COVID-19, the Spanish government declared a nationwide state of alarm in March 2020 which meant the home confinement of the entire country until May (2020). Seeking to explore what the practice of intergenerational leisure between grandparents and their 10-to-12-year-old grandchildren was like during that period, we decided to re-interview the same 357 grandparents via telephone.

Data were obtained from 272 grandparents during the lockdown, as the other 85 could not be contacted. 153 of those 272 grandparents (56.25\%) had grandchildren aged between 10 and 12, the target sample of this work. As for the age of the 153 grandparents interviewed, 37 had not reached the age of 65,73 were 65 -to-74-year-olds, and 43 were 75 years old or older.

A questionnaire elaborated ad hoc served to collect relevant information on:

1. Shared leisure. A dichotomous variable recorded whether grandparents shared any type of leisure activity with their grandchildren -it could be cultural, recreational, festive, digital, environmental-ecological, and/or solidary- through the question: "Do you share any activity [each of the aforesaid dimensions was specified] with your grandchild(ren) aged between 6 and 12?" The categories established were: yes/no. 
2. Periodicity with which leisure is shared; a categorical variable that brought together the sections of leisure time shared with the grandchild(ren), using the question "Indicate how often you perform each of the activities mentioned" with an 8-category Likert-type response scale ( $1=$ I do not share any leisure with my grandchild(ren); 2 $=$ only on vacation; $3=$ only 1 or 2 days a month; $4=$ on weekends, one day; $5=$ on weekends, both days; 6 = on weekdays, 1 or 2 days; 7 = on weekdays, 3 or 4 days; $8=$ on weekdays, all 5 days).

3. Types of benefits provided by the leisure shared with their grandchild(ren). 5 categorical variables (physical benefit; emotional well-being; creative benefit; manual benefit; and social benefit) gathered information on the contribution made by digital leisure to the grandparents' well-being, through five items: 1. "The leisure I share with my grandchild(ren) helps me stay fit, control my movements, and keep or improve my physical condition"; "The leisure time I share with my grandchild(ren) helps me feel happier, enjoy myself to a greater extent, and have more fun"; 3. "The leisure I share with my grandchild(ren) helps me be more creative"; 4. "The leisure I share with my grandchild(ren) helps me develop new manual abilities or perfect technical skills"; 5. "The leisure I share with my grandchild(ren) helps me (better) relate (better) to my grandchild(ren)". This information was collected by means of a 5-category Likert-type (response) scale ( 1 = (I) strongly disagree; 5 = (I) strongly agree).

4. Autonomous Region where the grandparent resided; a nominal variable made up of 5 possible responses to the question "Where do you live?": Cantabria; Castile and León; La Rioja; the Basque Country; and Navarre.

5. Year of birth; a numerical variable that recorded the age of the grandparents interviewed through the open item "Specify the year when you were born."

\subsection{Procedure}

This research initiative was approved by the Ethics Committee of the University of La Rioja (Spain) on December 17, 2019 (code CE_02_2019).

The questionnaire was applied to the grandparents of students from the different schools located in each of the 8 provinces that make up the northern part of Spain. The researchers gave the student body a consent form with information about the study for their parents and/or legal guardians to sign, in which they also had to write down the contact of the grandparent willing to participate. That form was subsequently delivered to the educational center.

Five duly trained researchers contacted the grandparents by phone and completed the questionnaire according to their testimonies before the pandemic and during the period of confinement. Each recording of answers lasted between 30 and 45 minutes on average.

\subsection{Data Analysis}

Data analysis developed in two stages using the SPSS 23.0 statistical program.

Firstly, a descriptive study carried out through the frequency statistic showed the periodicity of the leisure activities shared by the grandparents with their 6-to-12-year-old grand- 
children.

In the second stage, an inferential analysis based on the chi-square test $\left(\chi^{2}\right)$ and meant to fulfill the objectives of our study examined: (a) the presence of significant differences in the practice of digital leisure according to the geographical area where the grandparents resided; (b) the existence of significant differences in the practice of digital leisure depending on grandparents' age; and (c) the degree of correlation between the well-being derived from shared practice and the practice of digital leisure.

The level of significance established for this study was set at $p<.05$.

\section{RESULTS}

The shared practice of digital leisure logically underwent a radical change during confinement period. Before the pandemic, this type of leisure was the least shared by grandparents and grandchildren (except for solidarity-related activities, which had a completely residual scope) -only $20 \%$ carried out such activities. It ranked seventh out of 8 types of activities classified. Instead, it rose to first place during confinement because almost all grandparents and grandchildren shared this type of leisure (Figure 1).

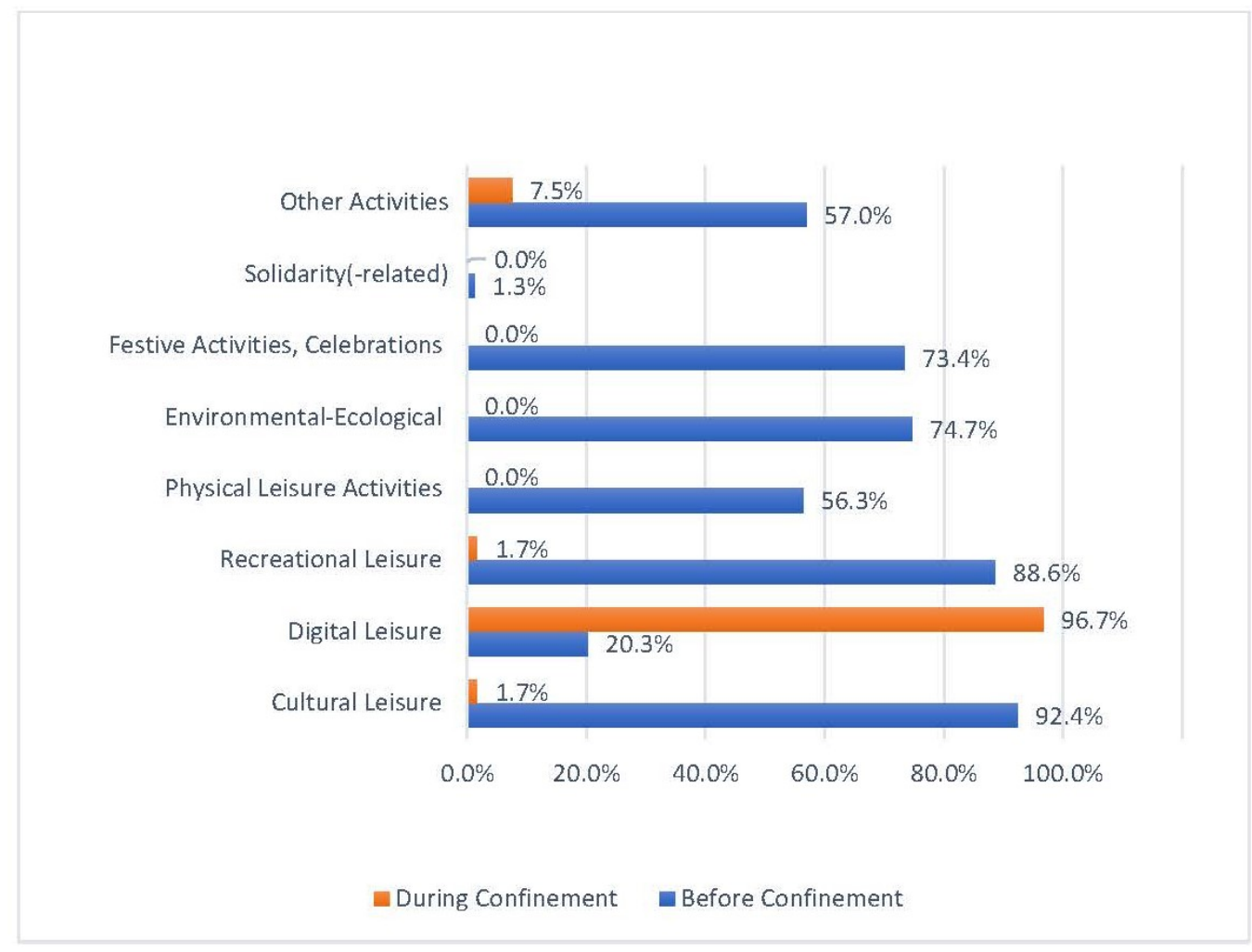

Figure 1 Type of activities practiced before and during lockdown

Specifically the activities performed evolved rather unevenly. Prior to the pandemic, all of these digital leisure activities were only carried out by a minority, none of them reaching 
$11 \%$ (Figure 2). In fact, they occupied positions 21,22 , and 24 among the 29 pre-classified activities.

During confinement, however, both technological online game playing and Internet browsing ceased to be practiced. In contrast, the use of social media reached almost the entire population, as it became the main means of communication between grandparents and grandchildren (Figure 2).

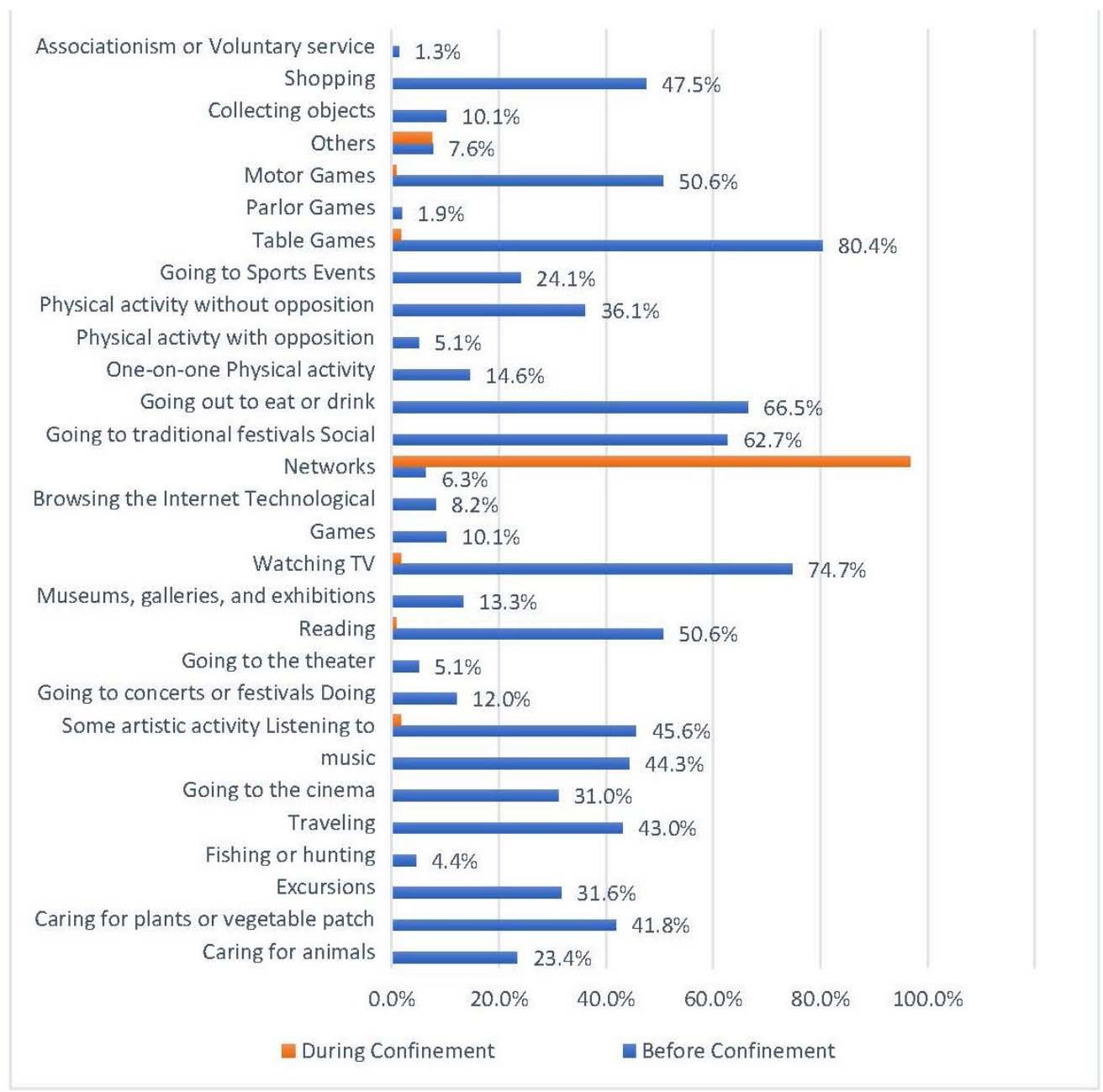

Figure 2 Activities shared by grandparents and grandchildren before and during lockdown

The frequency of performance was varied and changed radically during confinement too. Before confinement, digital leisure activities as a whole did not have a clear frequency. They were relatively sporadic and mostly carried out a maximum of two days a week. However, during confinement, this type of leisure was performed much more often on a daily basis: almost $39 \%$ of the grandparents shared digital leisure with their grandchildren 3 or 4 days a week (Figure 3). 


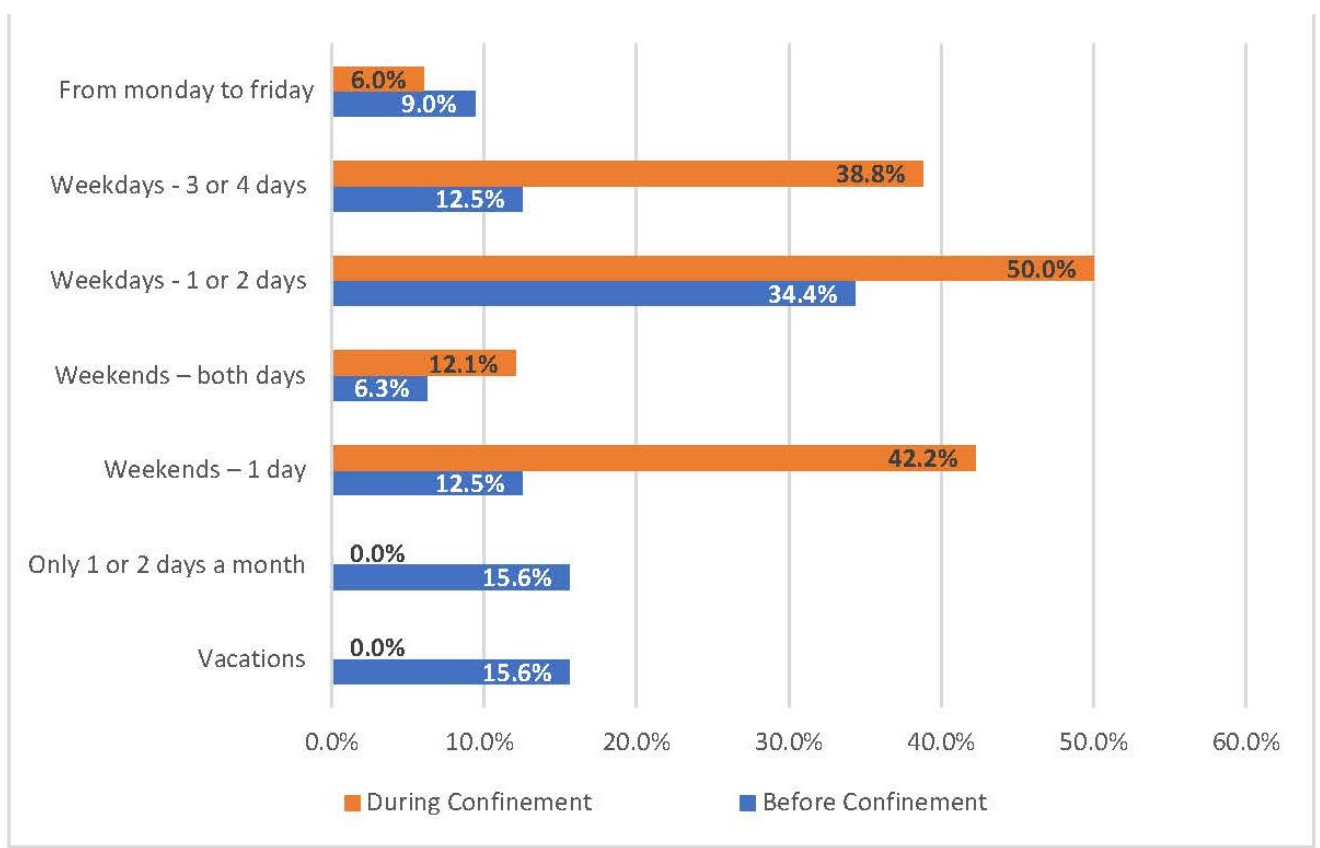

Figure 3 Frequency of digital activities before and during confinement

As for the specific activities, certain variations existed in their frequency before confinement. For example, media were used to a greater extent five days a week (almost 20\%), whereas online game playing became more sporadic ( $13 \%$ on vacation and almost $19 \%$ one or two days a month). All this changed during confinement, with no cases recorded of people who had browsed the Internet or played digital games throughout that period (Table 1).

Table 1 Grandparents who share Digital Leisure activities according to frequency before and during the confinement

\begin{tabular}{|c|c|c|c|c|c|c|c|c|}
\hline & & $\begin{array}{l}\text { Vaca- } \\
\text { tions }\end{array}$ & $\begin{array}{l}\text { Only } 1 \text { or } 2 \text { days } \\
\text { a month }\end{array}$ & $\begin{array}{l}\text { On } \\
\text { weekends. } 1 \\
\text { day }\end{array}$ & $\begin{array}{l}\text { On } \\
\text { weekends. } 2 \\
\text { days }\end{array}$ & $\begin{array}{l}\text { Weekdays } 1 \\
\text { or } 2 \text { days }\end{array}$ & $\begin{array}{l}\text { Weekdays } 3 \\
\text { or } 4 \text { days }\end{array}$ & $\begin{array}{l}\text { Weekdays } \\
5 \text { days }\end{array}$ \\
\hline \multirow[t]{3}{*}{$\begin{array}{l}\text { Before the } \\
\text { confinement }\end{array}$} & $\begin{array}{l}\text { Browsing the } \\
\text { Internet }\end{array}$ & $15.4 \%$ & $0.00 \%$ & $7.7 \%$ & $7.7 \%$ & $38.5 \%$ & $23.1 \%$ & $7.7 \%$ \\
\hline & $\begin{array}{l}\text { Social } \\
\text { Networks }\end{array}$ & $20.00 \%$ & $20.00 \%$ & $10.00 \%$ & $10.00 \%$ & $30.00 \%$ & $0.00 \%$ & $20.00 \%$ \\
\hline & $\begin{array}{l}\text { Technological } \\
\text { Games }\end{array}$ & $12.5 \%$ & $18.8 \%$ & $18.8 \%$ & $6.3 \%$ & $37.5 \%$ & $12.5 \%$ & $0.00 \%$ \\
\hline \multirow[t]{3}{*}{$\begin{array}{l}\text { During the } \\
\text { confinement }\end{array}$} & $\begin{array}{l}\text { Browsing the } \\
\text { Internet }\end{array}$ & $0.00 \%$ & $0.00 \%$ & $0.00 \%$ & $0.00 \%$ & $0.00 \%$ & $0.00 \%$ & $0.00 \%$ \\
\hline & $\begin{array}{l}\text { Social } \\
\text { Networks }\end{array}$ & $0.00 \%$ & $0.00 \%$ & $42.2 \%$ & $12.1 \%$ & $50.00 \%$ & $38.8 \%$ & $6.00 \%$ \\
\hline & $\begin{array}{l}\text { Technological } \\
\text { Games }\end{array}$ & $0.00 \%$ & $0.00 \%$ & $0.00 \%$ & $0.00 \%$ & $0.00 \%$ & $0.00 \%$ & $0.00 \%$ \\
\hline
\end{tabular}

In the stage before the pre-confinement, no significant differences existed in the percentage of digital leisure practiced according to grandparents' activities. 
Nevertheless, the pandemic leveled all these results, with almost all of the grandparents interviewed claiming that they shared the use of social media with their grandchildren (Table 2).

\begin{tabular}{|c|c|c|c|c|c|c|c|}
\hline & & Cantabria & Castile and León & Navarre & Basque Country & La Rioja & Other \\
\hline \multirow[t]{4}{*}{ Before the confinement } & Total Digital Leisure & $20.00 \%$ & $4.00 \%$ & $15.00 \%$ & $22.4 \%$ & $32.3 \%$ & $14.3 \%$ \\
\hline & Browsing the Internet & $6.7 \%$ & $4.00 \%$ & $0.00 \%$ & $12.1 \%$ & $12.9 \%$ & $0.00 \%$ \\
\hline & Social Networks & $6.7 \%$ & $0.00 \%$ & $5.00 \%$ & $5.2 \%$ & $9.7 \%$ & $14.3 \%$ \\
\hline & Technological Games & $13.3 \%$ & $0.00 \%$ & $10.00 \%$ & $12.1 \%$ & $16.1 \%$ & $0.00 \%$ \\
\hline \multirow[t]{4}{*}{ During the confinement } & Total Digital Leisure & $100.00 \%$ & $100.00 \%$ & $100.00 \%$ & $97.4 \%$ & $92.3 \%$ & $100.00 \%$ \\
\hline & Browsing the Internet & $0.00 \%$ & $0.00 \%$ & $0.00 \%$ & $0.00 \%$ & $0.00 \%$ & $0.00 \%$ \\
\hline & Social Networks & $100.00 \%$ & $100.00 \%$ & $100.00 \%$ & $97.4 \%$ & $92.3 \%$ & $100.00 \%$ \\
\hline & Technological Games & $0.00 \%$ & $0.00 \%$ & $0.00 \%$ & $0.00 \%$ & $0.00 \%$ & $0.00 \%$ \\
\hline
\end{tabular}

Data by age group did not provide statistically significant results, except for those regarding social media sharing $\left(\chi^{2}(6,601)=10.285 p=.037\right)$.

Before confinement, the results in the use of social media were inversely proportional to age. More specifically, the population over 74 years of age did not share social media with their grandchildren, and participation was higher among the group under 65 years of age (13.50\%) than among 65-to-74-year-olds (5.50\%). However, the highest levels of practice during confinement corresponded to the latter age range (98.30\%).

The cross-data between the perception of improvement and the performance of digital leisure activities or its lack will be presented next. Some differences become visible in the responses provided by people who share digital leisure and those who do not (Table 3). In other words, sharing digital leisure could imply a different perception of the benefits derived from this practice. Digital leisure shows a greater link with creativity $\left(\chi^{2}(4,126)=10.285\right.$ $p=.036$ ): $93.8 \%$ of the grandparents who share this type of practice consider that it helps them be more creative compared to $77.8 \%$ of those who do not practice digital leisure with their grandchildren. Differences also emerge in the perception of improved physical fitness and motor control $\left(\chi^{2}(4,126)=10.285 p=.036\right)$. In this case, there is a higher proportion of grandparents who believe that the leisure they share does not help them be fitter $(7.7 \%$ as opposed to $1.3 \%$ of those who do not practice digital leisure).

In the rest of questions, the responses state that sharing digital leisure improves grandparents' general condition (Figures 4, 5, 6, 7 and 8).

\section{DISCUSSION}

The results of this research reflect that most intergenerational leisure activities ceased to be carried out during confinement, except for those that could be performed from a distance, thanks to ICTs, which provided continuity to social and family interactions (Ayuso et al., 2020). 
Table 3 Pearson's chi-square tests: benefits of shared leisure

\section{Digital Leisure}

\begin{tabular}{|c|c|c|}
\hline \multirow{3}{*}{$\begin{array}{l}\text { BENEFITS The leisure I share with my grandchild(ren) helps me stay fit, better control my movements, } \\
\text { maintain or improve my physical condition (I am stronger, I run more...) }\end{array}$} & Chi-square & 12,373 \\
\hline & df & 4 \\
\hline & Sig. & $.015^{\star}$ \\
\hline \multirow{3}{*}{$\begin{array}{l}\text { BENEFITS The leisure I share with my grandchild(ren) helps me feel happier, I enjoy doing it, it amuses } \\
\text { me }\end{array}$} & Chi-square & 1,527 \\
\hline & df & 3 \\
\hline & Sig. & 0,676 \\
\hline \multirow[t]{3}{*}{ BENEFITS The leisure I share with my grandchild(ren) helps me become more creative } & Chi-square & 10,285 \\
\hline & df & 4 \\
\hline & Sig. & $.036^{*}$ \\
\hline \multirow{3}{*}{$\begin{array}{l}\text { BENEFITS The leisure I share with my grandchild(ren) helps me develop new manual abilities and } \\
\text { I acquire or perfect technical skills... }\end{array}$} & Chi-square & 4,005 \\
\hline & df & 4 \\
\hline & Sig. & 0,405 \\
\hline \multirow[t]{3}{*}{ BENEFITS The leisure I share with my grandchild(ren) helps me better relate to my grandchild(ren) } & Chi-square & 1,812 \\
\hline & df & 3 \\
\hline & Sig. & 0,612 \\
\hline
\end{tabular}

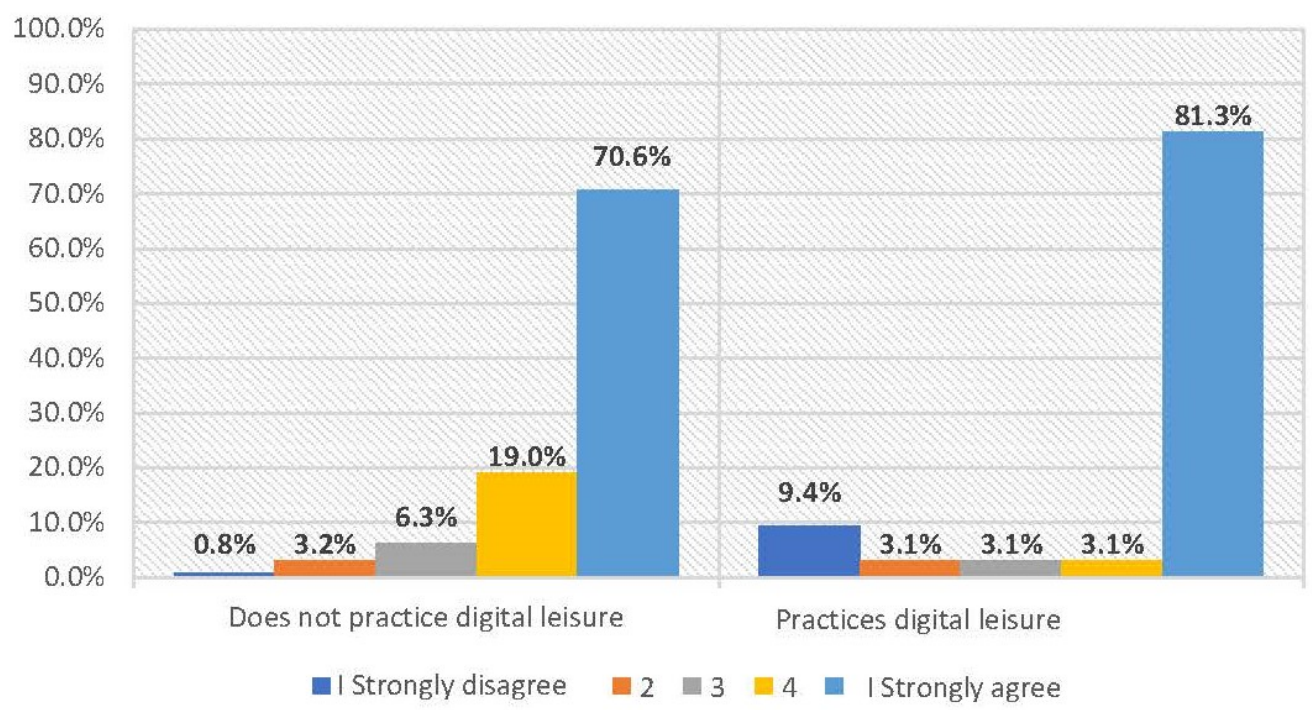

Figure 4 Improvement of grandparents' physical fitness due to the digital leisure shared with their grandchildren 


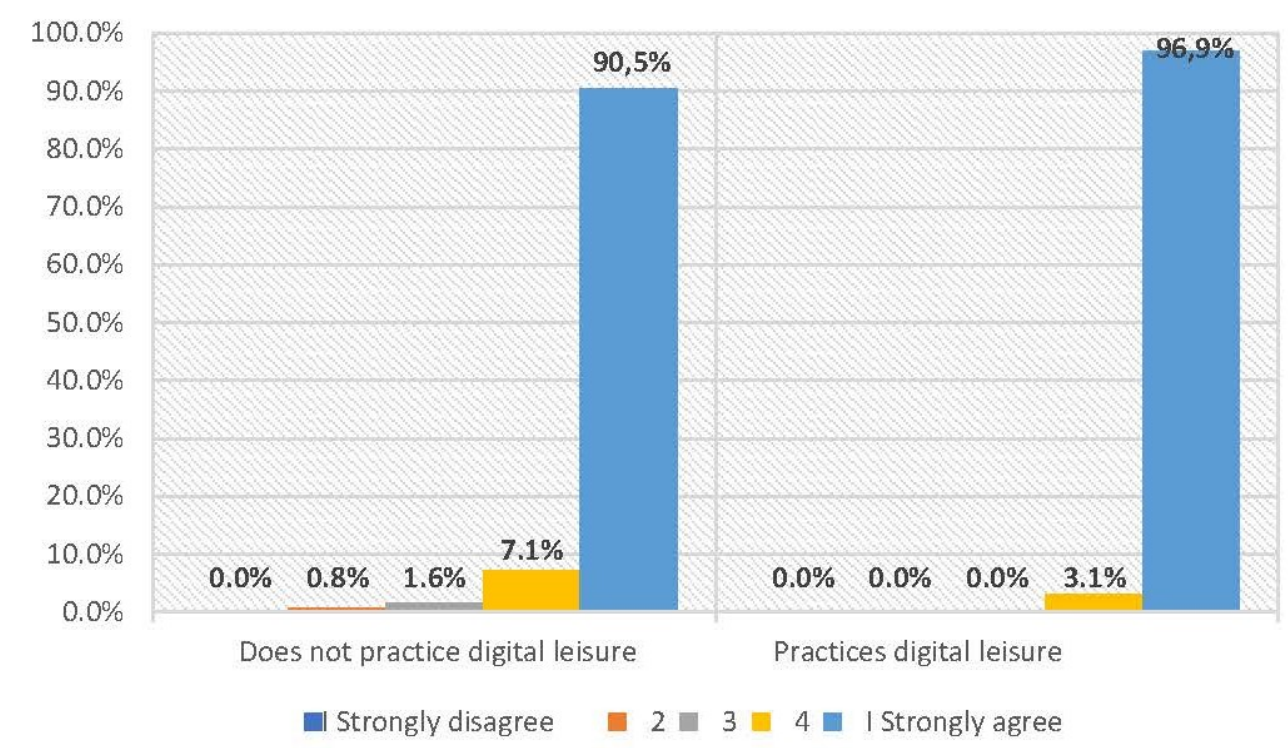

Figure 5 Grandparents' greater enjoyment and fun due to the sharing digital leisure with their grandchildren

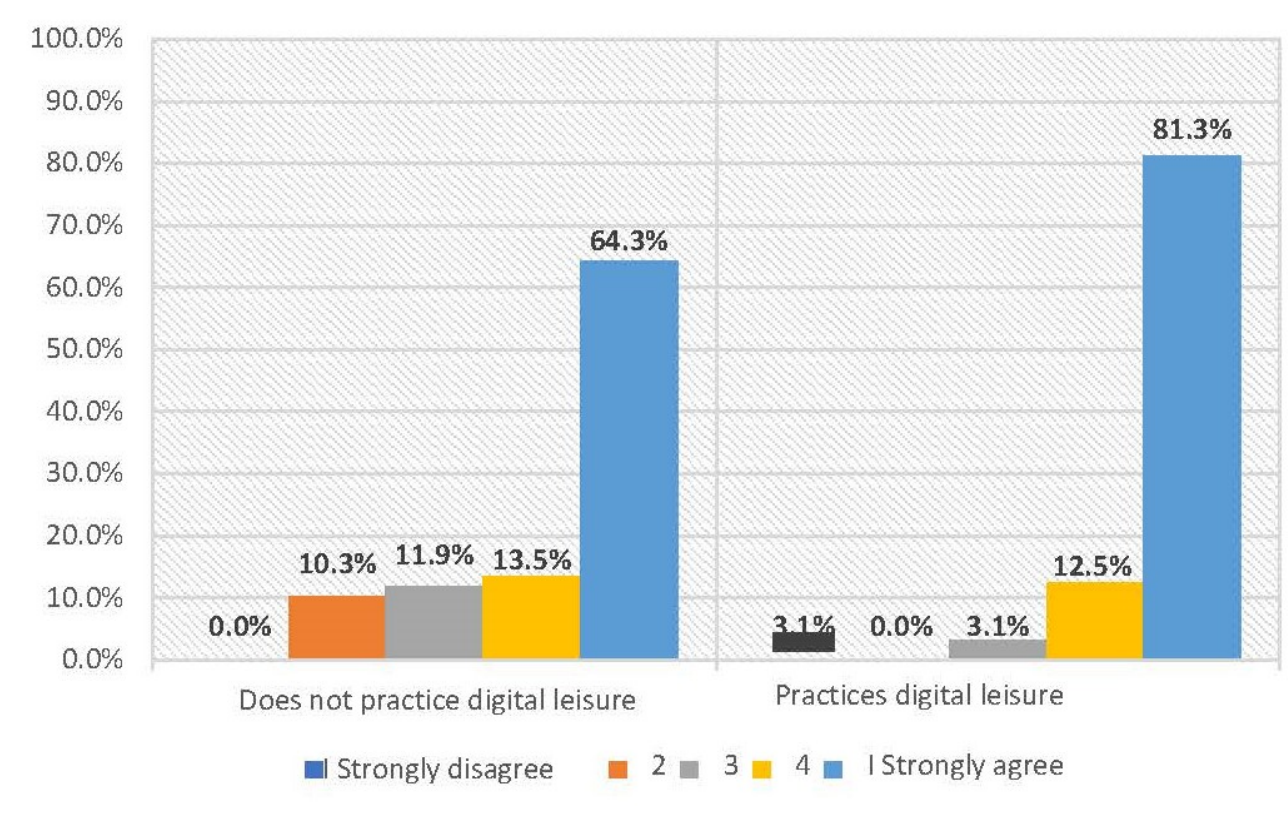

Figure 6 Grandparents' greater creativity due to the sharing digital leisure with their grandchildren 


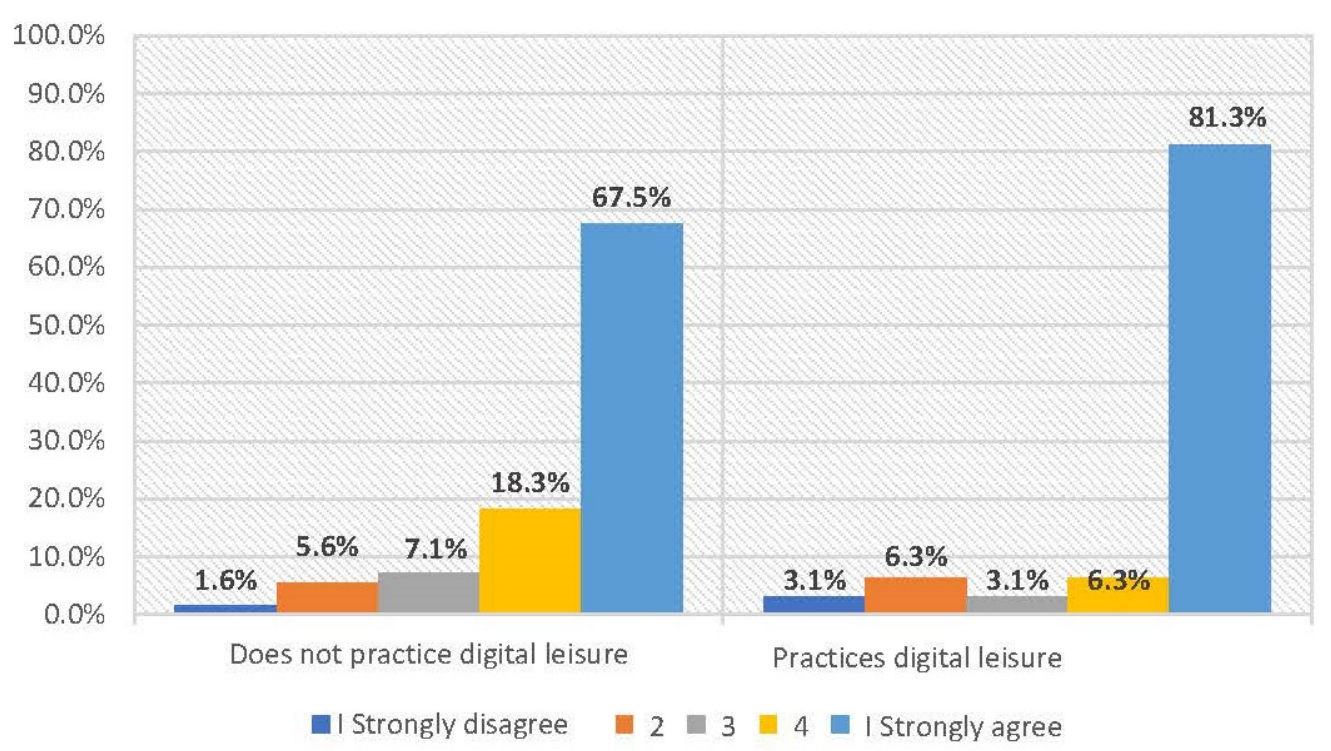

Figure 7 Grandparents' development of manual skills due to the sharing digital leisure with their grandchildren

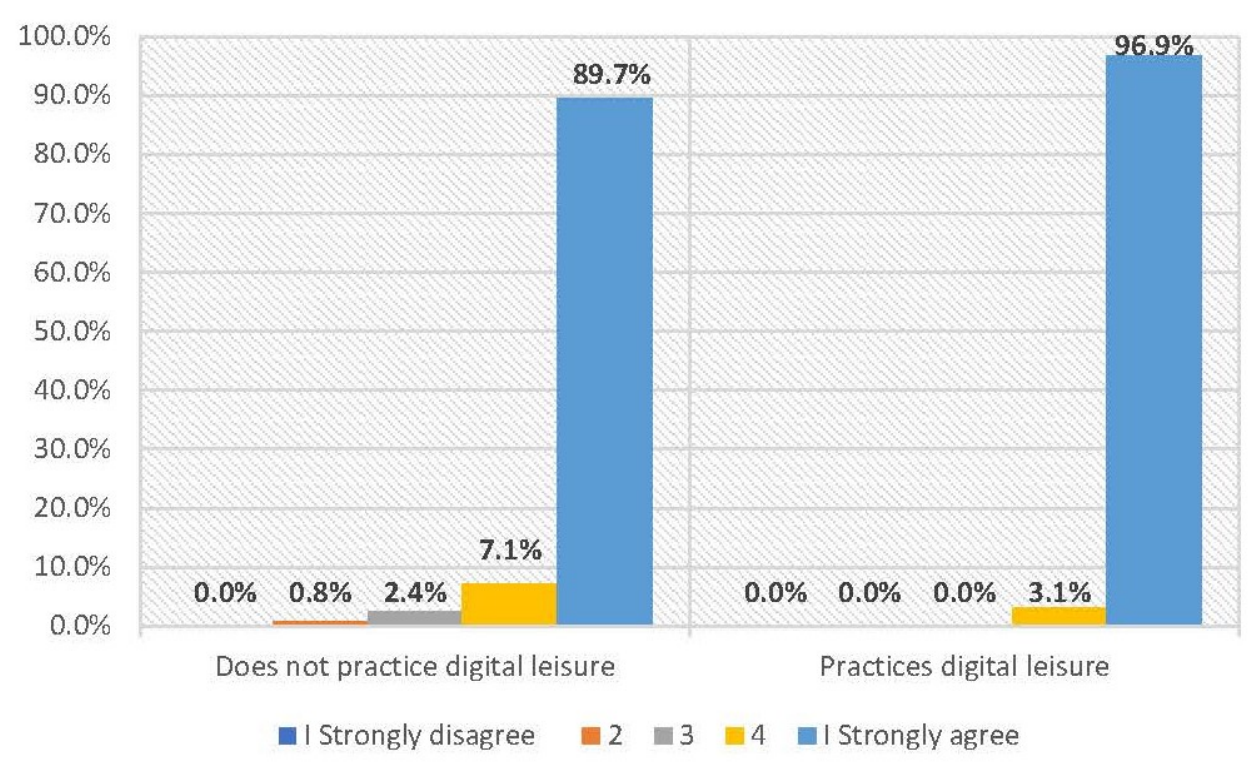

Figure 8 Improvement of grandparent/grandchild relationships due to the sharing digital leisure with their grandchildren 
Although the reality before the pandemic showed digital leisure activities as being secondary practices within intergenerational leisure, they came to occupy a preferential place during confinement. The use of social media reached almost the entire population under study and became practically the only intergenerational activity carried out during this time period. This reveals, on the one hand, the widespread use of social media among youth, and also that the main digital leisure habits of young Spaniards while at home involve interaction on social media, to which they grant more importance than to video game playing or browsing the Internet (García, López-De-Ayala, \& Catalina, 2013; Kahne, Lee, \& Timpany, 2011; Valdemoros et al., 2017; Zheng \& Cheok, 2011). And on the other hand, these preferences are in keeping with the fact that older people took advantage of the time spent in home confinement and the relationships with their grandchildren to adapt to the use of digital devices and social media, so that they could connect with their grandchildren and thus perform one of their preferred online participation practices (Freeman et al., 2020).

These findings highlight the great weight of the digital leisure time shared by grandparents and grandchildren during confinement, the frequency of its weekly practice considerably increasing in that period. Thus, technological connectivity between generations led to greater support for communication and meaningful relationships, in addition to a positive influence on the improvement of older people's quality of life and an impulse to facilitate active aging processes (Armitage \& Nellums, 2020; Arroyave et al., 2020; Ayuso et al., 2020; Casamayou \& Morales, 2017; Jones, 2020; Osorio et al., 2021; Rivoir et al., 2019).

This study also showed that there was no link between the practice of digital leisure and the autonomous region of residence. The reason for this lies in the fact that the confinement policies triggered by the COVID-19 pandemic were taken by the Spanish government to curb infections throughout the country and were applied equally in all the autonomous regions, limiting circulation to the coverage of basic needs.

The differences found before and during the confinement regarding grandparents' age in terms of sharing social networks confirm that the older the grandparents were, the less often this type of digital leisure was practiced. This supports the need to favor older grandparents' familiarization with technologies, which will enhance family communication with their grandchildren, thus reducing the existing "generational digital gap," as well as the rates of depression and loneliness among this population segment in a world that is so clearly mediated by digital technologies (Ayalon et al., 2021; J. Jimena, 2020; Martín-Romero, 2020).

On the other hand, the scientific literature confirms that the relationships between grandparents and grandchildren provide benefits to both generations (Coall \& Hertwig, 2010; González-Bernal \& Fuente, 2007; Kim et al., 2017; Pinazo \& Montoro, 2004). This study evidences that the leisure experiences shared by grandparents and grandchildren generally prove highly beneficial. However, sharing digital leisure does not imply a different perception of the benefits of shared leisure -except for the case of creativity and physical fitness- as it becomes evident that sharing digital leisure increases grandparents' contention about the way in which these practices improve their creativity. In contrast, the perception of benefits related to the improvement of physical fitness is less clear. 
Finally, as a limitation of the study, social desirability may have improved the well-being measures perceived by grandparents, as the scientific literature has given proof that individuals tend to increase the degree of satisfaction and happiness in their responses, especially when it comes to the subject under study (Caputo, 2015), which in turn implies intense affective and emotional links.

Having ascertained that intergenerational leisure generates psychological, physical, creative, and social benefits for grandparents, ultimately favoring a more active and satisfactory aging process (Badenes \& López, 2011; Martínez, 2017), it would be interesting for future research to determine whether the practice of shared digital leisure activity relates to increased levels of well-being among grandchildren.

\section{CONCLUSIONS}

The exceptionality of the current situation has entailed important changes in the grandparents/grandchildren relationship (Brooks et al., 2020; Dalton et al., 2020; Wang, Zhang, Zhao, Zhang, \& Jiang, 2020), boosting the use of digital technologies as a way to grant continuity to the private intergenerational relationships of physical contact (Ayuso et al., 2020; Jiménez et al., 2020).

This study confirms that the practice of intergenerational leisure improves grandparents' quality of life, generating high levels of well-being. And digital leisure arises as a strong link with the development of creativity.

The significance attributed to the intergenerational environment to intergenerational relationships shows the importance of expanding the role played by technology in intergenerational programs (Sánchez, Kaplan, \& Bradley, 2015). It also highlights how relevant the implementation of such programs can be to obtain models at an international level based on research outcomes to promote the well-being of all those involved (Canedo, García, \& Pacheco, 2014; Canedo et al., 2018).

Likewise, a compelling need exists to provide training resources for older grandparents who lack basic digital skills, especially taking into account the strong demand for digital infrastructures and services experienced during confinement. Among the activities demanded by the group of older people within the framework of intergenerational programs stood out digital activities, which they could perform them with their young grandchildren (Flores, Ortega, \& Vallejo, 2019). We need clearly regulated and affordables actions for everyone, from public and private entities as well as associations and educational institutions, that can build bridges between digital natives and immigrants and remove gaps that ultimately limit intergenerational relationships.

\section{ACKNOWLEDGEMENTS}

The text presented is associated with the research project "Leisure and well-being in an intergenerational perspective: from family daily life to social innovation in grandparentgrandchildren networks" (EDU2017-85642-R) [years 2017-2020], and serves as the basis of 
the current research project "Intergenerational leisure within the framework of the new normality. Education, opportunities and challenges" (PID2020-119438RB-I00) [years 20212024]; both financed through the National R\&D\&I Plan under two grants from the Ministry of Science and Innovation.

Funded by: Ministry of Science and Innovation, Spain

Funder Identifier: http://dx.doi.org/10.13039/501100004837

Award: EDU2017-85642-R; PID2020-119438RB-I00

\section{REFERENCES}

Alonso, R. A., Jubera, M. S. D., \& Sanz, E. (2020). Tiempos compartidos entre abuelos y nietos, tiempos de desarrollo personal. Revista Española de Pedagogía, 78(277), 415-433. https:// doi.org/10.22550/REP78-3-2020-01

Álvarez, L. V., Cala, K., \& Riaño, M. (2019). Estilos de personalidad de abuelos cuidadores y prácticas de crianza utilizadas con sus nietos. Revista Archivos Venezolanos de Farmacología $y$ Terapéutica, 38(5), 648-652.

Aranda, L. (2013). Doubling up: A gift or a shame? Multigenerational household and parental depression of older Europeans. Social Science and Medicine, 134, 12-22. https://doi.org/ 10.1016/j.socscimed.2015.03.056

Armitage, R., \& Nellums, L. B. (2020). COVID-19 and the consequences of isolating the elderly. The Lancet Public Health, 5(5). https://doi.org/10.1016/S2468-2667(20)30061-X

Arroyave, P. M., Ocampo, J., Sánchez, S. P., \& Vega, O. A. (2020). Inclusión digital como opción aportante al envejecimiento activo. e-Ciencias de la Información, 10(2). https://doi.org/10 .15517/eci.v10i2.39522

Attar-Schwartz, S., Tan, J. P., \& Buchanan, A. (2009). Adolescents' perspectives on relationships with grandparents: The contribution of adolescent, grandparent, and parent-grandparent relationship variables. Children and Youth Services Review, 31(9), 1057-1066. https://doi.org/10.1016/ j.childyouth.2009.05.007

Ayalon, L., Chasteen, A., Diehl, M., Levy, B. R., Neupert, S. D., Rothermund, K., ... Wahl, H. W. (2021). Aging in times of the COVID-19 pandemic: Avoiding ageism and fostering intergenerational solidarity. Journals of Gerontology: Psychological Sciences, 76(2), 49-52. https:// doi.org/10.1093/geronb/gbaa051

Ayuso, L., Requena, F., Jiménez, O., \& Khamis, N. (2020). The effects of COVID-19 confinement on the Spanish Family: Adaptation or change. Journal of Comparative Family Studies, 51(3-4), 274-287. https://doi.org/10.3138/jcfs.51.3-4.004

Badenes, N., \& López, M. T. (2011). Doble dependencia: abuelos que cuidan nietos en España. Revista de Servicios Sociales, 49, 107-125. https://doi.org/10.5569/1134-7147.49.09

Barrio, A. D., \& Gutiérrez, I. (2015). Las TIC una mirada a los hábitos de los adolescentes que viven con sus abuelos. International Journal of Developmental and Educational Psychology: INFAD. Revista de Psicología, 1(1), 251-264. https://doi.org/10.17060/ijodaep.2015.n1.v1.97

Brooks, S. K., Webster, R. K., Smith, L. E., Woodland, L., Wessely, S., Greenberg, N., \& Rubin, G. J. (2020). The psychological impact of quarantine and how to reduce it: Rapid review of the evidence. The Lancet, 395, 30460-30468. https://doi.org/10.1016/S0140-6736(20)30460-8

Buchanan, A. (2008). Involved grandparenting and child well-being. Full Research Report ESRC End of Award Report, RES-000-22-2283. ESRC.

Cambero, S. (2020). Sociología de las relaciones familiares e intergeneracionales en periodo pandémico. In A. Vázquez-Atochero (Ed.), Reflexiones desconfinadas para la era posCOVID- 
19 (pp. 105-134). AnthropiQa 2.0.

Canedo, A., García, J. N., \& Pacheco, D. I. (2014). Educación intergeneracional de forma virtual. International Journal of Developmental and Educational Psychology. INFAD Revista de Psicología, 1(3), 345-352. https://doi.org/10.17060/ijodaep.2014.n1.v3.512

Canedo, A., Pachero, D. I., García, J. N., \& Gonçalves, S. R. (2018). Promoción del vínculo intergeneracional a través de los medios digitales. International Journal of Developmental and Educational Psychology, 2, 131-138.

Caputo, A. (2015). Social desirability bias in self-reported well-being measures: Evidence from an online survey. Universitas Psichologica, 16(2), 93-102. https://doi.org/10.11144/Javeriana .upsy16-2.sdsw

Carcavilla, N. (2014). Campamentos intergeneracionales y nuevas tecnologías en el cuidado de la persona mayor. International Journal of Developmental and Educational Psychology. INFAD Revista de Psicología, 2(1), 365-368.

Casamayou, A., \& Morales, M. J. (2017). Personas mayores y tecnologías digitales: desafíos de un binomio. Psicología, Conocimiento y Sociedad, 7(2), 199-226. https://doi.org/10.4206/ rev.austral.cienc.soc.2019.n36-15

Cloquell, A. (2015). Usos sociales de Internet entre los adolescentes españoles. Revista sobre la Infancia y la Adolescencia, 8, 1-14. https://doi.org/10.4995/reinad.2015.3649

Coall, D. A., \& Hertwig, R. (2010). Grandparental investment: Past, present, and future. Behavioral and Brain Sciences, 33, 1-59. https://doi.org/10.1017/S0140525X09991105

Colás, P., González, T., \& Pablos, J. D. (2013). Juventud y redes sociales: motivaciones y usos preferentes. Comunicar, 40(20), 15-23. https://doi.org/10.3916/C40-2013-02-01

Dalton, L., Rapa, E., \& Stein, A. (2020). Protecting the psychological health of children through effective communication about COVID-19. The Lancet Child \& Adolescent Health, 4(5), 3009730100. https://doi.org/10.1016/S2352-4642(20)30097-3

Drury, L., \& Bobrowicz, A. (2017). The positive and negative impact of an intergenerational digital technology education programme on younger people's perceptions of older adults. In J. Zhou \& G. Salvendy (Eds.), Human Aspects of IT for the Aged Population. Aging, Design and User Experience. ITAP 2017 (pp. 419-428). Springer. https://doi.org/10.1007/978-3-319-58530-7 $\_32$

Espinar, E., \& González, M. J. (2009). Jóvenes en las redes sociales virtuales: un análisis exploratorio de las diferencias de género. Feminismo/s, 14, 87-105. https://doi.org/10.14198/fem.2009.14 .06

Flores, M. J., Ortega, M. C., \& Vallejo, S. (2019). Experiencias inclusivas intergeneracionales: ¿un nuevo horizonte para la inclusión de personas mayores y menores? Miscelánea Comillas, 77(150), 139-152.

Freeman, S., Marston, H. R., Olynick, J., Musselwhite, C., Kulczycki, C., Genoe, R., \& Xiong, B. (2020). Intergenerational effects on the impacts of technology use in later life: Insights from an international, multi-site study. International Journal of Environmental Research and Public Health, 17(16), 5711-5711. https://doi.org/10.3390/ijerph17165711

García, A., López-De-Ayala, M. C., \& Catalina, B. (2013). Hábitos de uso en internet y en las redes sociales de los adolescentes españoles. Comunicar, 41, 195-204. https://doi.org/10.3916/ C41-2013-19

González-Bernal, J., \& Fuente, R. (2006). La relación entre abuelos y nietos según la edad del nieto. International Journal of Developmental and Educational Psychology, 2(1), 303-313.

González-Bernal, J., \& Fuente, R. (2007). Intergenerational grandparent/grandchild relations: The socioeducational role of grandparents. Educational Gerontology, 34, 67-88. https://doi.org/ $10.1080 / 03601270701763993$ 
Hera, T. D. L., Loos, E., Simons, M., \& Blom, J. (2017). Benefits and factors influencing the design of intergenerational digital games: A systematic literature review. Societies, 7(3), 18. https:// doi.org/10.3390/soc7030018

Jimena, J. (2020). Programa intergeneracional para combatir la exclusión social adolescente y la brecha digital en personas de la tercera edad. In E. Sánchez-Rivas, E. Colomo-Magaña, J. RuizPalmero, \& J. S. Rodríguez (Eds.), Tecnologías educativas y estrategias didácticas (pp. 10621071). Universidad de Málaga.

Jimena, R. (2017). Dificultades intergeneracionales en la comunicación interpersonal por el uso de las tecnologías. Revista PUCE, 104, 189-218. https://doi.org/10.26807/revpuce.v0i0.67

Jiménez, A., Santillán, J., Montoro, D., Rodríguez, M. M., Muñoz, F. J., \& Arrogante, O. (2020). Increase in video consultations during the COVID-19 pandemic: healthcare professionals' perceptions about their implementation and adequate management. International Journal of Environmental Research and Public Health, 17(14), 5112. https://doi.org/10.3390/ ijerph17145112

Jones, X. R. (2020). Covid-19: An exposition, with a focus on social isolation in the elderly (UK). The Open University.

Kahne, J., Lee, N., \& Timpany, J. (2011). The civic and political significance of online participatory cultures and youth transitioning to adulthood. DML Central Working Papers.

Kim, H. J., Kang, H., \& Johnson-Motoyama, M. (2017). The psychological well-being of grandparents who provide supplementary grandchild care: A systematic review. Journal of Family Studies, 23, 118-141. https://doi.org/10.1080/13229400.2016.1194306

Llamas, F., \& Pagador, I. (2014). Estudio sobre las redes sociales y su implicación en la adolescencia. Enseñanza \& Teaching: Revista Interuniversitaria de Didáctica, 32(1), 43-57. http://doi.org/ 10.14201/et20143214357

Lloyd, J. (2008). The state of intergenerational relations today. International Longevity Centre UK.

Luna, S., Ramos, P., \& Rivera, F. (2016). Coping strategies, stress and health of grandmothers caring for ascending and descending relatives. Studies in Psychology, 37(1), 90-114. https://doi.org/ 10.1080/02109395.2015.1122435

MacCallum, J., Palmer, D., Wright, P., Cumming-Potvin, W., Northcote, J., Booker, M., \& Tero, C. (2006). Community building through intergenerational exchange programs. National Youth Affairs Research Scheme.

Martínez, A. L. (2017). El rol de agentes educativos en los abuelos del siglo XXI: transmisión de valores y principales factores que influyen en el grado de relación mantenida con sus nietos. La Razón Histórica. Revista Hispanoamericana de Historia de las Ideas, 37, 44-76.

Martín-Romero, A. M. (2020). La brecha digital generacional. Temas laborales: Revista Andaluza de Trabajo y Bienestar Social, 151, 77-93.

Miguel, S. M. D., Escarbajal, A., \& Moreno, P. (2012). El rol de los abuelos en la relación con sus nietos. Una aproximación cualitativa desde el punto de vista socioeducativo. In M. G. PérezSerrano (Ed.), Envejecimiento activo y solidaridad intergeneracional: claves para un envejecimiento activo (pp. 1-35). UNED.

Ochaita, E., Espinosa, M. A., \& Gutiérrez, H. (2011). Las necesidades adolescentes y las nuevas tecnologías de la información y la comunicación. Revista de Estudios de Juventud, 92, 87110.

Osorio, P., Jorquera, P., \& Araya, M. (2021). Vejez y vida cotidiana en tiempos de pandemia: estrategias, decisiones y cambios. Horizonte Antropológico, 59, 227-243. https://doi.org/10.1590/ s0104-71832021000100012

Pinazo, S., \& Montoro, J. (2004). La relación abuelos y nietos. Factores que predicen la calidad de la relación intergeneracional. Revista Internacional de Sociología, 38, 147-168. https://doi.org/ 


\subsection{9/ris.2004.i38.257}

Ramos, P. (2019). Claves para el desarrollo del rol de abuelo y abuela en la sociedad española actual. Estudios de Psicología, 40(2), 283-311. https://doi.org/10.1080/02109395.2019.1583468

Reis, L., Mercer, K., \& Boger, J. (2021). Technologies for fostering intergenerational connectivity and relationships: Scoping review and emergent concepts. Technology in Society, 64, 101494101494. https://doi.org/10.1016/j.techsoc.2020.101494

Rivoir, A., Morales, M. J., \& Casamayou, A. (2019). Usos y percepciones de las tecnologías digitales en personas mayores. Limitaciones y beneficios para su calidad de vida. Revista Austral de Ciencias Sociales, 36, 295-313. https://doi.org/10.4206/rev.austral.cienc.soc.2019.n36-15

Sánchez, M., Kaplan, M., \& Bradley, L. (2015). Usando la tecnología para conectar las generaciones consideraciones sobre forma y función. Comunicar, 45, 95-104. https://doi.org/10.3916/ C45-2015-10

Subrahmanyam, K., Greenfield, P. M., \& Michikyan, M. (2015). Comunicación electrónica y relaciones adolescentes. Una actualización de las investigaciones existentes. Infoamérica: Iberoamerican Communication Review, 9, 115-130.

Triadó, C. (2000). El rol de abuelo: cómo perciben los abuelos las relaciones con sus nietos. Revista Española de Geriatría y Gerontología, 35(2), 30-36.

Triadó, C., Martínez, G., \& Villar, F. (2000). El rol y la importancia de los abuelos para sus nietos adolescentes. Anuario de Psicología, 81, 107-118.

Valdemoros, M. A., Alonso, R. A., \& Codina, N. (2018). Actividades de ocio y su presencia en las redes sociales en jóvenes potencialmente vulnerables. Revista Interuniversitaria, 31, 71-80. https://doi.org/10.7179/PSRI_2018.31.06

Valdemoros, M. A., Sanz, E., \& Ponce, A. (2017). Ocio digital y ambiente familiar en estudiantes de postobligatoria. Comunicar, 50, 99-108. https://doi.org/10.3916/C50-2017-09

Wang, G., Zhang, Y., Zhao, J., Zhang, J., \& Jiang, F. (2020). Mitigate the effects of home confinement on children during the COVID-19 outbreak. The Lancet, 395(10228), 945-947. https://doi .org/10.1016/S0140-6736(20)30547-X

Zheng, R., \& Cheok, A. (2011). Singaporean adolescents' perceptions of online social communication: An exploratory factor analysis. Journal Educational Computing Research, 45(2), 203-221. https://doi.org/10.2190/EC.45.2.e 